\title{
Assessment Model Impact of Climate Change on Potential Production for Food and Energy Needs for the Coastal Areas of Bengkulu, Indonesia
}

\author{
Eko Sumartono $^{1 \bullet}$, Gita Mulyasari², Ketut Sukiyono ${ }^{2}$ \\ ${ }^{1}$ Student for Doctoral Program in Agricultural Science, University of Bengkulu and Lecturer in \\ Agribusiness, Faculty of Agriculture, Universitas Dehasen Bengkulu \\ ${ }^{2}$ Lecturer at the Doctoral Program in Agricultural Science, Bengkulu University \\ ^Corresponding author email: ekosumartono@ relawanjurnal.id
}

\begin{abstract}
Bengkulu is said to be the center of the world's climate because of the influence of water conditions and the topography of the area where the rain cloud formation starts. The waters in Bengkulu Province become a meeting place for four ocean currents which eventually become an area where the evaporation process of forming rain clouds becomes the rainy or dry season and affects the world climate. Method to analyze descriptively, shows oldeman Classification and satellite rainfall estimation data is added. In relation to the Analysis of Potential Food Availability for the Coastal Areas of Bengkulu Province uses a quantifiable descriptive analysis method based. The results show that most are included in the Oldeman A1 climate zone, which means it is suitable for continuous rice but less production due to generally low radiation intensity throughout the year. In an effort to reduce or eliminate the impact of climate change on food crop production, it is necessary to suggest crop diversification, crop rotation, and the application of production enhancement technologies. Strategies in building food availability as a result of climate change are: First, develop food supplies originating from regional production and food reserves on a provincial scale. Second, Empowering small-scale food businesses which are the dominant characteristics of the agricultural economy, especially lowland rice and horticultural crops. Third, Increase technology dissemination and increase the capacity of farmers in adopting appropriate technology to increase crop productivity and business efficiency. Four, Promote the reduction of food loss through the use of food handling, processing and distribution technologies.
\end{abstract}

Keywords: climate change; coastal areas; food and energy needs; model; potential production.

\section{INTRODUCTION}

Climate information is needed, especially in agriculture. Indonesia, which is an agricultural country, really needs climate information, especially the climate classification in each region. The climate classification system that is widely used in Indonesia is the Oldeman classification. The Oldeman classification is used because it relates the relationship between climate, plant type, and the appropriate planting time of a place. Oldeman's climate classification uses the element of rainfall as the basis for determining his climate classification. Rainfall patterns in a year play an important role in making climate classification information in a region (Oldeman L.R. dan M. Frere, 1982). Rainfall patterns in the Indonesian region are dominated by the influence of several phenomena, including the Asia-Australia, El-Nino, East-West (Walker Circulation) and North-South (Hadley Circulation) circulation systems as well as several circulations due to local influences such as those already mentioned. described (Hermawan, 2010). Monsoon and the movement of the ITCZ (Intertropical Convergence Zone) are closely related to variations in annual and semi-annual rainfall in Indonesia (Aldrian \& Dwi Susanto, 2003; Tjasyono et al., 2004). This monsoon regulates the climate in parts of the Indian continent which results in warm wet seasons and dry winters (Berliana, 2006). Local wind circulation also affects climatic conditions, especially the process of circulation of land winds and sea breezes (Bannu, 2003). The monsoon wind period is seasonal, while the land and sea winds are daily (Tjasyono, 2006).

Indonesia is an agricultural country where agriculture plays an important role in the entire national economy. This can be shown from the number of people or workers who live or work in the agricultural sector and national products derived from agriculture. The agricultural sector is very vulnerable to climate change because it affects cropping patterns (Md. Naimur, 2020; Parker Id et al., 2019; Passeri et al., 2016), planting time (Yao et al., 2015), production (Smith \& Gregory, 2013), development of 
pests (Stoeckli et al., 2012)and quality of yields (Peltonen-Sainio et al., 2016).

The Agency for the Assessment and Application of Technology (BPPT) argued, based on recent research, Bengkulu Province is considered to be the center of the world's climate. the provisional results of the research, the rain clouds in Indonesia are mostly formed in Bengkulu. The cloud moves to spread throughout the Maritime Continent of Indonesia and other countries in the world. "In general, the clouds that are formed are Cumulonimbus (cb) clouds (BPTP, 2015)

Bengkulu is the center of climate because of the influence of water conditions and the topography of the area where the rain cloud formation starts. The waters in Bengkulu Province become a meeting place for four ocean currents which eventually become an area where the evaporation process of forming rain clouds becomes the rainy or dry season and affects the world climate (BPTP, 2015; Republika, 2015) .

The first sea current, called the All-Year Season flow, moves from the waters of Aceh Province to West Sumatra and ends in Bengkulu waters or moves from northwest to southeast. The current meets the Indonesian Cross current moving from the south of Java Island. Indonesian monsoons from the Sunda Strait, and the Southern equatorial currents originating from the Indian Ocean. The meeting of these currents occurs a water cycle and forms a fairly large rain cloud (BPTP, 2015). So this condition Bengkulu Province has a different tropical climate character.

Problems From Tropical Climate Regions Classically, the tropical climate is divided into two: wet tropical and dry tropical. De Wall divides tropical climates into 10 classifications based on average daily temperatures and the difference between day and night temperatures. In this grouping, only cities or regions that have an average daily temperature of $28^{\circ} \mathrm{C}$ or more are included in the tropical climate category.
Details about this source text are required for the source text to obtain additional translation information. The characteristic that stands out in a tropical climate is the high average daily temperature compared to other climates. One of the problems caused by this climate in relation to the city as a place for humans to live and carry out daily work activities is as follows:

1. Warming caused by solar radiation, the sun emits radiant heat to the earth's surface. The heat emitted by the sun to the earth's surface does not depend on whether the earth's surface is a city (urban) or a village (rural), but is more subject to the angle of fall - radiation will reach a maximum amount of $90^{\circ}$ fall angle, as well as depending on cloud conditions that can block it. the radiation emission. The implication of radiation to the earth's surface will be different when the surface has different characters in terms of absorption and reflection of the radiation.

2. The occurrence of 'Heat Urban Island' Due to the closure of the ground surface by concrete (which can be in the form of buildings or pavement) and asphalt (roads and parking lots), most of the solar radiation that falls on the surface is absorbed and then released again into the air above. and surrounding. The heat release absorbed by hard materials such as concrete or asphalt will be much greater than what occurs in plants. Because most of the city area is covered by hard materials, the city air temperature is higher than the surrounding area which is still rural. This phenomenon is often referred to as a heat urban island, where the physical area of the city seems to be an island radiating heat in the middle of a green expanse of a rural area.

The objectives of this study are as follows: 1. Knowing the impact of climate change on socio-economic development in Bengkulu Province by looking at the Classification Analysis of Old Man which is used because it links the relationship between climate, type of plant, and the correct planting time in a place? 2. How is the food availability strategy of Province Bengkulu related to the potential of production 
with food needs and energy potential for food production needs as a result of climate change?

\section{METHODS}

Matching the results of data analysis used by (Paski, 2017) is monthly rainfall data from 13 rainpoints in Bengkulu as well as satellite rainfall data for TMPA (TRMM Multisatellite Precipitation Analysis) and IMERG (Integrated Multisatellite Retrievals for GPM) level 3 (3B43) ) to analyze descriptively the potential of the Bengkulu coastal area. According to (Paski, 2017), states that the TMPA and IMERG products used are rainfall estimation data using satellites with a spatial resolution of $0.25 \mathrm{o} \times 0.25 \mathrm{o}$, the data period used is from 1998 to 2016. The TRMM and GPM grids used include Bengkulu region, namely $5^{\circ} 40$ 'latitude - $2^{\circ} 0^{\prime}$ latitude and $100^{\circ}$ 40 'east longitude - $104^{\circ} 0^{\prime}$ l longitude. Popular rain post data from various cities and districts, such as Table 1. The number of raindrops and BMKG stations connecting 16 and the number of satellite grid points (TRMM and GPM) installed are 169, so the total data used is 185 points (see, Figure 2).

The limitation of rainfall data from rain posts is the background for the use of satellite data (TRMM and GPM), satellite data is used as a complement to the distance of rain post points. In the study (Paski, 2017)used TRMM data type 3B43 Version 7, abbreviated as 3B43V7, which can be downloaded on the website http://disc.sci.gsfc.nasa.gov, TRMM data and GPM 3B43V7 are level 3 rainfall estimation data which various corrections have been made, including the addition of other satellite data that requires further correction. The TRMM and GPM download data formats are in the form of netCDF (network Common Data Form), where the netCDF (.nc) data is extracted according to the specified grid and converted to ASCII format. Data extraction and conversion uses the Python 2.7 program language .

In relation to the assessment model impact of climate change on potential production for food and energy needs for the coastal areas of bengkulu in its development, the linkage of production with food and energy needs as a result of climate change uses a quantifiable descriptive analysis method based on the results of several previous scientific studies of researchers.

\section{RESULTS AND DISCUSSION}

\section{Climate Classification Assessment Model In Bengkulu Province}

Bengkulu Province is a coastal area which is located on the west coast of Sumatra, directly adjacent to the Indian Ocean and in the east it is surrounded by a series of hillside mountain ranges, this causes Bengkulu province to have very distinctive weather conditions. The flow of air masses originating from high evaporation in the Indian Ocean which is moving towards Bengkulu province is uplifted after being blocked by the Bukit Barisan mountains so that the growth of convective clouds is very intensive. Bengkulu region generally has an equatorial rain type with maximum rain peaks in March and December (Paski, 2015). When viewed from the geographical and topographical location factors, climate classification is very much needed for the Bengkulu region, however Bengkulu Province only has a few rain observation points. The latest data shows rain posts that have made observations with a duration of more than 19 years with good data quality are 13 cooperative rain posts and $3 \mathrm{BMKG}$ stations. The minimal number of rain post points cannot produce an optimal Oldeman Classification agro-climate map, to complement the distance of rain post points, satellite rainfall estimation data is added.

The criteria put forward by Oldeman were based on the number of Wet Months (BB) and Dry Months (BK). From the calculations carried out, the amount of rainfall of $200 \mathrm{~mm} /$ month is considered sufficient to cultivate lowland rice. For a rainfall of $100 \mathrm{~mm} /$ month it is considered sufficient to cultivate secondary crops.

Oldeman L.R. dan M. Frere (1982) in Tjasyono et al. (2004) also defines wet 
months as months with total rainfall> $200 \mathrm{~mm} /$ month and dry months as months with $<100 \mathrm{~mm} /$ month, while months with rainfall between $100 \mathrm{~mm}-200 \mathrm{~mm}$ are humid months. The main type of Oldeman's classification is based on the number of consecutive wet months, namely: zone A, zone $\mathrm{B}$, zone $\mathrm{C}$, zone $\mathrm{D}$, and zone $\mathrm{E}$. While the subtypes are based on the number of consecutive dry months, namely: zone 1, zone 2, zone 3 and zone 4 (Lakit, 1994). The characteristics of these zones differ from one another which is called the agro-climate zone. The agro-climate zone is then mapped into an agro-climate map that can be used as a reference for planting both agriculture and plantations.
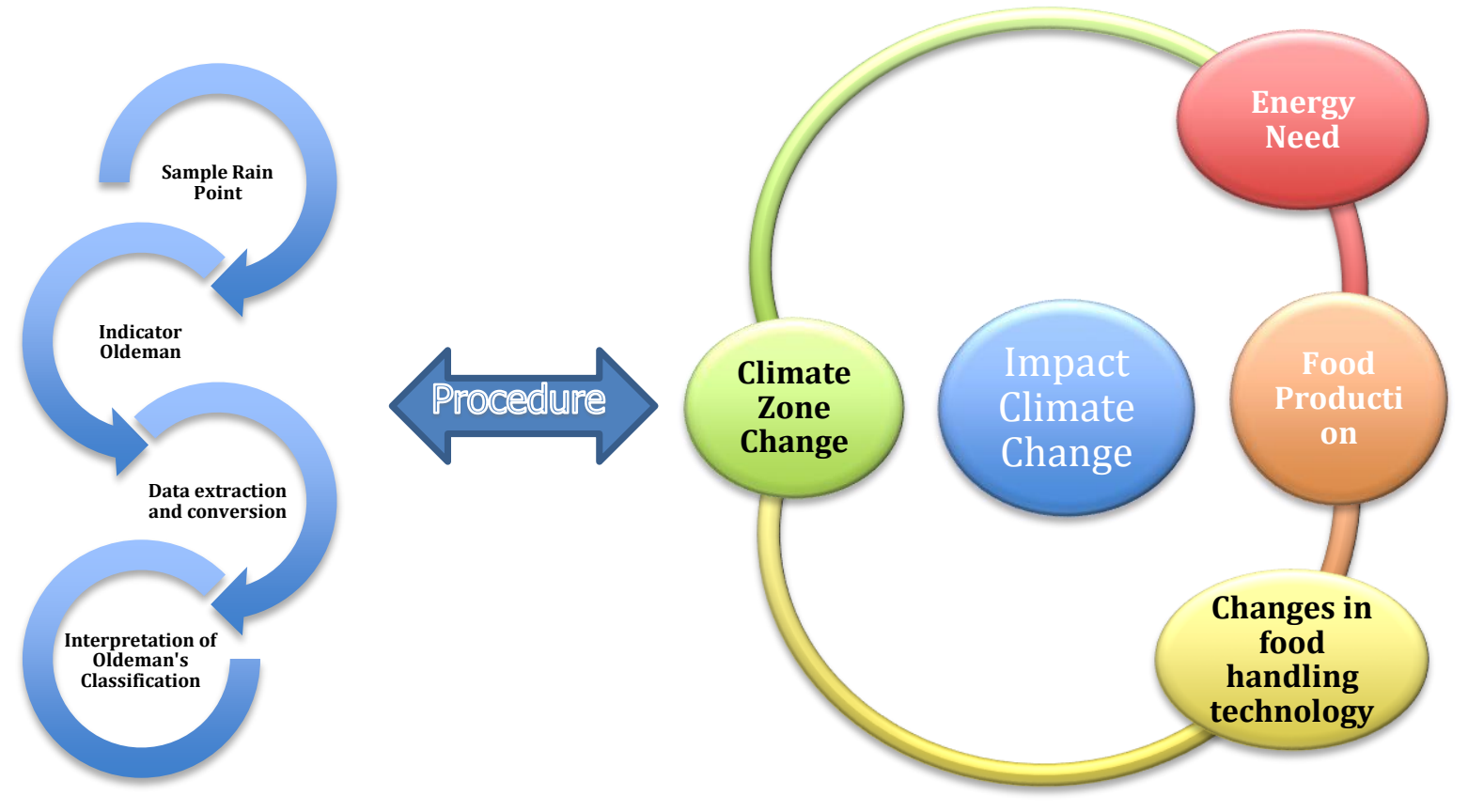

Figure 1. Assessment model impact of climate change

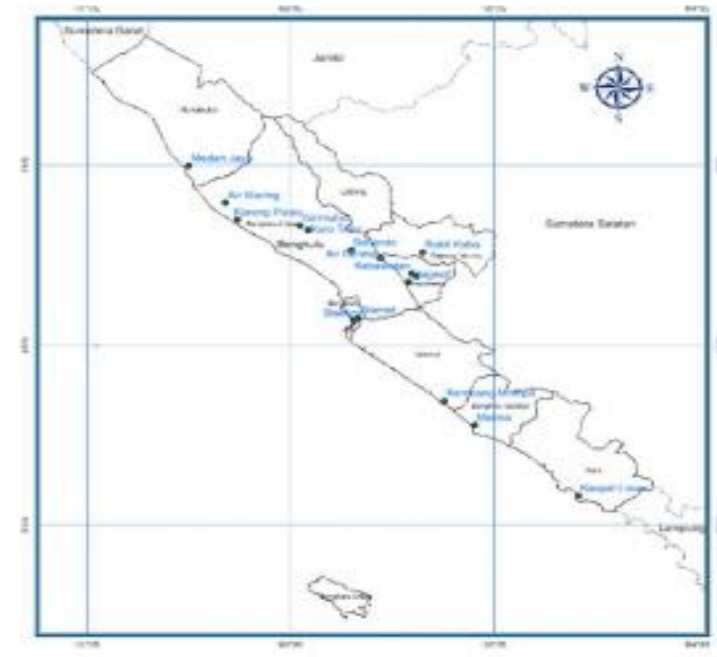

(a)

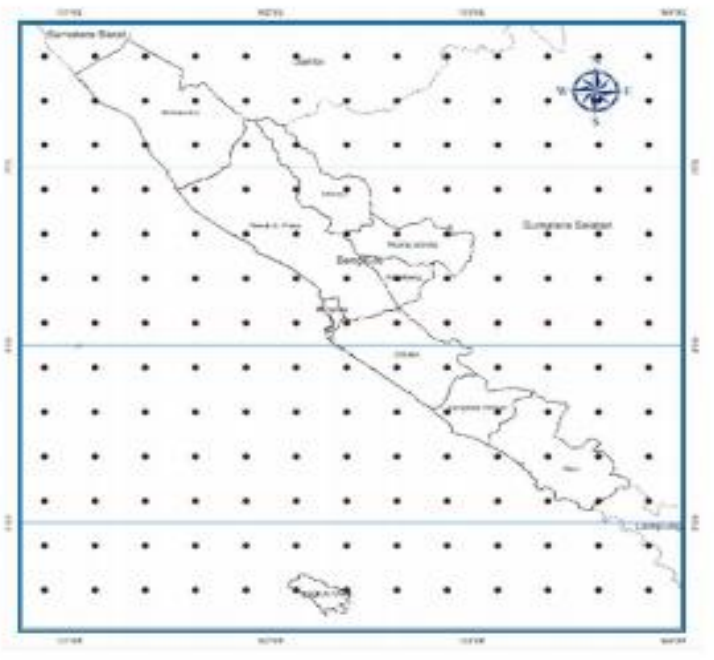

(b)

Figure 2. Post Distribution (a) Rain and Grid Point Distribution for TMPA and IMERG (b) 
Table 1. Average Monthly Rainfall 1998-2016 (mm)

$\begin{array}{lcccccccccccc}\text { Pos Point Rainfall } & \text { Jan } & \text { Feb } & \text { March } & \text { Apr } & \text { May } & \text { June } & \text { July } & \text { August } & \text { Sept } & \text { Oct } & \text { Nov } & \text { Dec } \\ \text { Air Bening } & 267 & 212 & 210 & 288 & 216 & 145 & 179 & 177 & 192 & 249 & 294 & 303 \\ \text { Air Muring } & 287 & 223 & 229 & 259 & 192 & 213 & 192 & 271 & 286 & 355 & 370 & 342 \\ \text { Baturoto } & 512 & 398 & 432 & 532 & 422 & 298 & 377 & 308 & 396 & 421 & 598 & 472 \\ \text { Bukit Kaba } & 257 & 191 & 204 & 284 & 180 & 113 & 142 & 156 & 143 & 237 & 269 & 258 \\ \text { Giri Mulyo } & 320 & 266 & 265 & 315 & 280 & 269 & 216 & 236 & 224 & 366 & 399 & 349 \\ \text { Kabawetan } & 387 & 290 & 326 & 314 & 219 & 139 & 181 & 148 & 164 & 268 & 408 & 426 \\ \text { Kanpel Linau } & 234 & 199 & 177 & 176 & 223 & 153 & 165 & 232 & 255 & 287 & 428 & 342 \\ \text { Karang Pulau } & 242 & 182 & 195 & 240 & 167 & 166 & 160 & 241 & 206 & 286 & 350 & 231 \\ \text { Kelobak } & 398 & 331 & 410 & 395 & 272 & 120 & 171 & 139 & 145 & 305 & 474 & 490 \\ \text { Kembang Mumpo } & 260 & 186 & 195 & 213 & 165 & 135 & 191 & 216 & 290 & 305 & 390 & 309 \\ \text { Kuro Tidur } & 283 & 231 & 227 & 258 & 233 & 211 & 182 & 210 & 218 & 373 & 341 & 306 \\ \text { Manna } & 284 & 260 & 237 & 235 & 219 & 168 & 269 & 303 & 409 & 414 & 468 & 415 \\ \text { Medan Jaya } & 266 & 229 & 173 & 250 & 164 & 171 & 185 & 234 & 250 & 269 & 382 & 291 \\ \text { Meteorological } & 348 & 260 & 293 & 296 & 210 & 173 & 191 & 210 & 196 & 279 & 420 & 447 \\ \text { Station } & 355 & 302 & 306 & 318 & 196 & 132 & 134 & 114 & 140 & 267 & 384 & 423 \\ \text { Geophysical Station } & 356 & 311 & 281 & 213 & 205 & 187 & 203 & 209 & 273 & 437 & 481\end{array}$

Source : BMKG Station Provinsi Bengkulu, 2018

Data from 13 cooperative rain posts and BMKG stations in the Bengkulu region (Table 1), it can be seen that the average monthly rainfall in several regions has more wet months (> $200 \mathrm{~mm}$ ) than dry months (Paski, 2017).

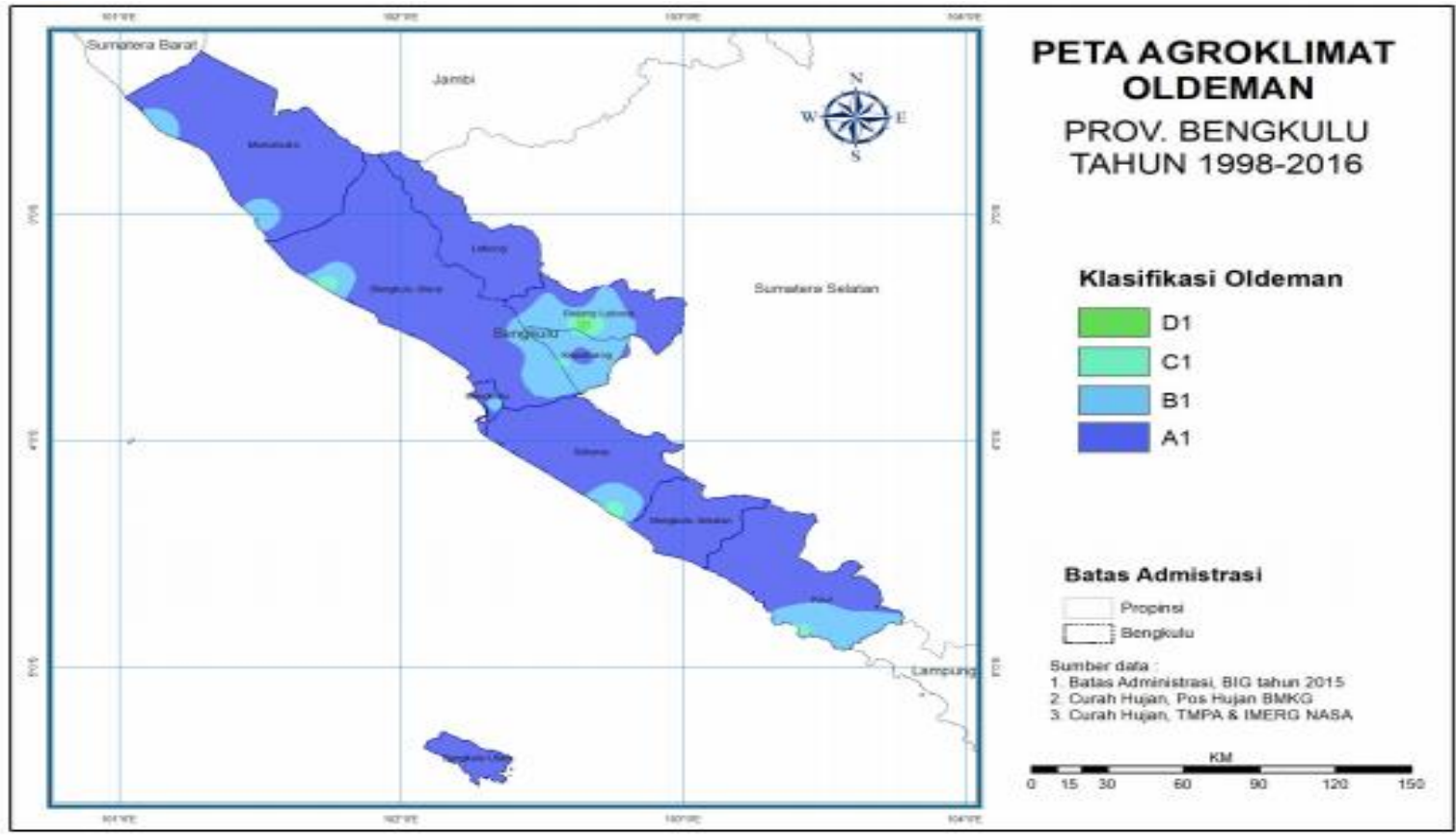

Figure 3. Map of Agro-climate in Oldeman Province, Bengkulu

Based on the map of the results of the Agro-climatic distribution of the Oldeman climate classification (see Figure 3),
Bengkulu Province has 4 types of climate, namely types $\mathrm{A} 1, \mathrm{~B} 1, \mathrm{C} 1$, and $\mathrm{D} 1$. Of Bengkulu's $19,788 \mathrm{~km} 2$ area, the majority of 
climate type A1 reaches $83.9 \%$, climate type $\mathrm{A} 1$ is as much as $4.8 \%$, climate type $\mathrm{C} 1$ is $1.2 \%$ and climate type D1 is as much as $0.1 \%$. The districts of Lebong and Bengkulu Selatan only have one climate classification, namely A1. Muko-muko Regency and Bengkulu City have 2 types of climate, namely $\mathrm{A} 1$ and $\mathrm{B} 1$. For districts that have 3 types of climate (A1, B1, and C1), namely North Bengkulu, Seluma and Kaur. Especially for Rejang Lebong Regency, it has 4 types of climate, namely A1, B1, C1, and D1. The breadth of climate type A1 indicates that based on the rainfall factor most of the areas in Bengkulu are suitable for continuous rice but production is lacking due to generally low radiation intensity throughout the year. As many as $4.8 \%$ of the area in Bengkulu is suitable for continuous rice with good planning at the beginning of the planting season and high production when the harvest is dry season, for areas that can plant rice once and crops twice a year as much as $1.2 \%$ and the area for planting aged rice short one time and usually high bias production due to high radiation flux density with sufficient cropping time of $0.1 \%$.

Table 2. Interpretation of Oldeman's Classification

\begin{tabular}{|l|l|}
\hline Climate Tipe & \multicolumn{1}{c|}{ Information } \\
\hline A1; A2 & $\begin{array}{l}\text { Suitable for continuous rice but less production due to general intensity } \\
\text { low radiation all year round high radiation. The time for planting crops is } \\
\text { sufficient }\end{array}$ \\
\hline B1 & $\begin{array}{l}\text { Suitable for continuous paddy with good early season planning. } \\
\text { Production is high when the harvest is dry season }\end{array}$ \\
\hline B2; B3 & $\begin{array}{l}\text { Can plant rice twice a year with varieties of short life and dry season short } \\
\text { enough for crops }\end{array}$ \\
\hline C1 & Can plant rice once and secondary crops twice a year \\
\hline C2;C3;C4 & $\begin{array}{l}\text { A year, you can only plant rice once and the second crop of crops must be } \\
\text { careful not to fall in dry months }\end{array}$ \\
\hline D1 & $\begin{array}{l}\text { Plant short-lived rice once and usually the production is high due to the } \\
\text { flux density }\end{array}$ \\
\hline D2;D3;D4 & $\begin{array}{l}\text { Maybe only once rice or once crops a year, depending on the availability } \\
\text { irrigation water supply }\end{array}$ \\
\hline E & $\begin{array}{l}\text { This area is generally too dry, maybe you only get one secondary crop, } \\
\text { that too depending on the rain }\end{array}$ \\
\hline
\end{tabular}

Source: Table Oldeman's Classification (Paski, 2017)

Observations of 13 cooperative rain posts and 3 BMKG stations in the Bengkulu region show that the average monthly rainfall has more wet months ( $>200 \mathrm{~mm}$ ) than dry months $(<100 \mathrm{~mm})$. The addition of rainfall estimation data from satellite images can increase the density and distribution of rainfall in Bengkulu Province by using linear corrections, resulting in a better Oldeman classification map. The results show that most of the areas in Bengkulu Province are included in the Oldeman A1 climate zone, which means it is suitable for continuous rice but less production due to generally low radiation intensity throughout the year.

However, other impacts related to climate are closely related to climate change and global warming can reduce agricultural production by 5-20 percent. Climate change is a condition characterized by changing world climate patterns which results in erratic weather phenomena. Climate change occurs due to changes in climate variables, such as air temperature and rainfall, which 
occur continuously over a long period of time between 50 and 100 years. Climate change is also influenced by unstable weather conditions, for example erratic rainfall, frequent storms, extreme air temperatures, and drastic changes in wind direction.

\section{Food Availability Strategy as a Impact of Climate Change}

The main capital in realizing food availability is the wealth of diverse resources, the availability of technology, and the development of strategic partnerships with various stakeholder components between regions in Bengkulu Province. Food availability is the first of the three subsystems in the food security system and the base of efforts to achieve food independence and sovereignty. The four strategies proposed in building food availability are as follows.

First, the Bengkulu Provincial Government needs to build a food supply originating from regional production and food reserves on a provincial scale. If the two food sources cannot fulfill or fulfill the needs, then the food supply can be from areas outside Bengkulu province through the national food supply balance mechanism.

Second, to empower small-scale food businesses which are the dominant characteristics of the agricultural economy, especially rice and horticultural crops, it is necessary to: (a) harmonize or integrate small-scale food business activities into the food supply chain and ( b) efforts to collect small-scale farms so as to achieve economies of scale by applying socio-economic engineering such as corporate farming or contract farming in a certain scale between regions within districts and cities.

Third, boosting technology dissemination and increasing the capacity of farmers in adopting appropriate technology to increase crop productivity and business efficiency. One of the operational steps that can be taken is to increase the capacity of extension workers and farmers, both from the technical aspect and managerial capability in managing the farm where reliable extension agents are prepared as a result of climate change.

Fourth, promote the reduction of food loss through the use of food handling, processing and distribution technologies. Increasing the accessibility of farmers physically and economically to food processing technology is mandatory and absolutely necessary.

\section{Potential Production With Food Needs As The Impact of Climate Change}

(1) In an effort to reduce or eliminate the impact of climate change on food crop production, it is necessary to suggest crop diversification, crop rotation, and the application of production enhancement technologies. In Indonesia, especially in Bengkulu, reducing the impact of climate change can technically be pursued through several efforts. Identifying areas of drought, flooding, endemic pests and plant diseases based on climatic conditions, soil conditions and local culture;

(2) Developing techniques for predicting and predicting accurate climate factors in order to provide early warning to farmers about imminent climate change;

(3) Preparing a cultivation technology package that is able to adapt to El Nino and La Nina conditions, covering cropping patterns, varieties, pest and disease control, as well as inputs that are easily accessible to farmers;

(4) Improve irrigation channels, especially paddy fields to increase production capacity and prevent crop failure during the dry season, especially in rice production centers. (5) Increase the productivity of farming, especially in the fields of plantation and lowland rice farming, namely the use of certified or standardized quality and quality seeds as well as the use of balanced fertilizers. Fertilizer must be available and on time according to farmers' needs. Farming productivity increases according to standards and ultimately leads to the welfare of 
farmers. So "Certified seeds are a necessity that must be met, so that productivity can be achieved. The issue of seeds is not only at the level of availability but also about affordability and distribution, "

Food crop development must take into account local land and climatic conditions. Not a single component of cultivation technology is the best in all locations given the variety of abiotic, biotic, social, economic and cultural conditions of farmers. One of the technological innovations in rice, corn and soybean production that takes into account local conditions is the Rice Expert System (SIPADI), the Corn Expert System (SIPAJA), the Soybean Expert System (SIPALE).

This expert system integrates computer programs designed to model the problemsolving abilities faced by farmers in a specific location. The variables in this model consist of soil physical, climate, plant nutrition, pests and diseases, weeds, socioeconomic conditions, and labor. Moreover, at this time Bengkulu has been supported by changes in the irrigation system which have begun to be activated again, such as the Majunto Reservoir Irrigation, and several reservoir irrigation which are being built such as in Padang Guci, Seginim-Kedurang Irrigation has been reactivated. So that it can support sustainable coastal food agriculture in accordance with local wisdom. For example, there is local wisdom in the community, such as in Kaur Regency. Repung: Forms of Community Local Wisdom in the Agricultural Sector which has a historical aspect, the area is ecologically a combination of rice fields and cultivation, the people strive for these two sectors. In the fields, rice is planted while in the fields, besides being planted with rice, the fields are also planted with export commodity crops such as coffee, rubber, and so on.

This is closely related to the condition of the location of agricultural land which is on high land and lowland so that it affects the type of rice planted. Broadly speaking, there are two types of rice planted, namely lowland rice and lowland rice. Rice basically relies on water supply. There are at least several types of rice fields, namely: rice fields with skylights, living rice fields, swampy rice fields, tidal fields, moor and fields or huma (dry rice) that do not rely on water. Livinglean rice fields are almost evenly distributed throughout the area. These rice fields are routinely irrigated either by means of waterwheels or river dams. Rice fields with the sky always depend on their water supply from rainwater. Repung is land provided by the community to be planted with food crops by each clan. The planted land is carbohydrate-producing plants. This repung works very well during an emergency, when the danger of starvation threatens. At that time, food shortages often occurred when drought hit the community.

Other conditions also need to develop in the community plantation system that has been passed down from generation to generation where the plantation expert system is activated as well, for example the Coffee Plantation Expert system (SIBUN KOPI), the Oil Palm Plantation Expert System (Marginal Land that needs to be developed) (SIBUN SAWIT), the Spice Plantation System ( SIPARE) as well as horticultural farming systems (especially in the highlands) of Bengkulu Province such as Rejang Lebong and Kepahyang.

\section{Energy Potential For Food Production} Needs In Anticipating Climate Change

Along the coastal area of Bengkulu Province, it is known that there are 124 large and small rivers which upstream in the Bukit Barisan area and flow westward, which empties into the Indian Ocean. The existence of rivers that flow along the coastal areas of Bengkulu Province, has a mutually influencing relationship.

The types of rivers that exist along the coastal areas of Bengkulu Province generally have relatively straight and short flow characteristics, where this condition encourages high rates of erosion in damaged river basins. The high rate of erosion results 
in a very large volume of transported sediment, which causes high turbidity in the river estuary area. Some of the rivers that flow along the coastal areas of Bengkulu Province are used for irrigation purposes, such as the Kedurang River, Padang Guci River, Air Nipis River, Suangai Air Nalas, Air Seluma River, Air Padang River, and M Contino River.

In an effort to fulfill water as a need for agricultural production in Bengkulu province as a whole. Utilization of the energy potential of river water in an effort to ensure food availability in Bengkulu province needs to be carried out with various infrastructure developments such as the addition of reservoirs, embungs, and irrigation channels. Currently, Bengkulu has been supported by changes in the irrigation system which has begun to be activated again, such as Irrigation for the Majunto Reservoir, and several reservoir irrigation which are being built, such as in Padang Guci, Seginim-Kedurang Irrigation has been reactivated. However, an increase is needed so that it can be maximally boosted production needs in several agricultural areas in Bengkulu province as a result of climate change. The potential of other non-biological resources in Bengkulu Province in the form of mining, maritime and energy materials is enormous. Climate change that affects coastal areas is not only detrimental to fishermen's agriculture, but can also benefit lowland rice farming and horticulture. An example of an energy that is rarely utilized from the maritime sector is the use of wind energy (Bayu) to meet production needs in the agricultural sector and horticultural food crops. If this is utilized, what will happen is the rise of the agricultural sector in coastal areas by utilizing wind energy (wind) to generate electricity which can be used to turn on water pumps when the dry season arrives as an alternative solution.

\section{CONCLUSION}

Observations of 13 cooperative rain posts and 3 BMKG stations in the Bengkulu region show that the average monthly rainfall has more wet months $(>200 \mathrm{~mm}$ ) than dry months $(<100 \mathrm{~mm})$. The results show that most of the areas in Bengkulu Province are included in the Oldeman A1 climate zone, which means it is suitable for continuous rice but less production due to generally low radiation intensity throughout the year. In an effort to reduce or eliminate the impact of climate change on food crop production, it is necessary to suggest crop diversification, crop rotation, and the application of production enhancement technologies.

The four strategies in building food availability as a result of climate change are that the First, Bengkulu Provincial Government needs to build a food supply originating from regional production and food reserves on a provincial scale. Second, Empowering small-scale food businesses which are the dominant characteristics of the agricultural economy, especially lowland rice and horticultural crops. Third, increasing technology dissemination and increasing the capacity of farmers in adopting appropriate technology to increase crop productivity and business efficiency. Fourth, promote the reduction of food loss through the use of food handling, processing and distribution technologies. Increase Production Potential in an effort to increase food demand as a result of climate change. Maximizing the potential for energy to meet production needs in anticipation of climate change through infrastructure development such as the addition of reservoirs, embungs, and repair of irrigation channels and the use of wind technology (wind).

\section{REFERENCES}

Aldrian, E., \& Dwi Susanto, R. (2003). Identification Of Three Dominant Rainfall Regions Within Indonesia And Their Relationship To Sea Surface Temperature. International Journal Of Climatology Int. J. Climatol, 23, 14351452. Https://Doi.Org/10.1002/Joc. 950 Bannu. (2003). Analisis Interaksi Monsun, Enso Dan Dipole Mode Serta Kaitannya 
Dengan Variabilitas Curah Hujan Dan Angin Permukaan Di Benua Maritim Indonesia. In Tesis ITB, Bandung.

Berliana. (2006). The Spectrum Analysis Of Meteorological Elements In Indonesia, Thesis, Nagoya University, Japan.

BPTP. (2015). Bengkulu Jadi Pusat Iklim Dunia | Republika Online. 2015. Https://Nasional.Republika.Co.Id/Berit a/Nasional/Daerah/15/12/24/Nzuzki382 -Bengkulu-Jadi-Pusat-Iklim-Dunia

Hermawan, E. (2010). 75 Pengelompokkan Pola Curah Hujan Yang Terjadi Di Beberapa Kawasan P. Sumatera Berbasis Hasil Analisis Teknik Spektral Pengelompokkan Pola Curah Hujan Yang Terjadi Di Beberapa Kawasan P. Sumatera Berbasis Hasil Analisis Teknik Spektral.

Md. Naimur, R. (2020). Crops Pattern Change And Agricultural Diversification: A Case Study Of Domar Upazila, Nilphamari. International Journal of Agricultural Science And Food Technology, 6(1), 022-029.

Https://Doi.Org/10.17352/2455-

815x.000050

Oldeman L.R. Dan M. Frere. (1982). A Study Of The Agroclimatology Of The Humid Tropics Of South-East Asia. WMO Interagency Project On Agroclimatology.

Parker Id, L., Bourgoin, C., Martinez-Valle, A., \& Lä Derach, P. (2019). Vulnerability Of The Agricultural Sector To Climate Change: The Development Of A Pan-Tropical Climate Risk Vulnerability Assessment To Inform Sub-National Decision Making.

Https://Doi.Org/10.1371/Journal.Pone. 0213641

Paski. (2017). (PDF) Pemetaan Agroklimat

Klasifikasi Oldeman Di Provinsi

Bengkulu Menggunakan Data Observasi Permukaan Dan Multi Satelit (TMPA Dan IMERG) Oldeman Classification Of Agroclimate Mapping
In Bengkulu Province Based On Ground Observation And Multisatellite Da. Https://Www.Researchgate.Net/Publica tion/324861139_Pemetaan_Agroklimat _Klasifikasi_Oldeman_Di_Provinsi_B engkulu_Menggunakan_Data_Observa si_Permukaan_Dan_Multi_Satelit_TM PA_Dan_IMERG_Oldeman_Classifica tion_Of_Agroclimate_Mapping_In_Be ngkulu_Province_Ba

Paski, J. A. I. Dan A. (2015). Penggolongan Sel Awan Konvektif Penyebab Angin Kencang Di Pesisir Barat Bengkulu Berdasarkan Gema Citra Radar (Studi Kasus 22 Februari 2014).

Passeri, N., Blasi, E., Franco, S., Martella, A., Pancino, B., \& Cicatiello, C. (2016). The Environmental Sustainability Of National Cropping Systems: From Assessment To Policy Impact Evaluation. Land Use Policy, 57, 305312.

Https://Doi.Org/10.1016/J.Landusepol. 2016.06.007

Peltonen-Sainio, P., Jauhiainen, L., \& Lehtonen, H. (2016). Land Use, Yield And Quality Changes Of Minor Field Crops: Is There Superseded Potential To Be Reinvented In Northern Europe? Https://Doi.Org/10.1371/Journal.Pone. 0166403

Republika. (2015). Bengkulu Jadi Pusat Iklim Dunia | Republika Online. Https://Nasional.Republika.Co.Id/Berit a/Nasional/Daerah/15/12/24/Nzuzki382 -Bengkulu-Jadi-Pusat-Iklim-Dunia

Smith, P., \& Gregory, P. J. (2013). Climate Change And Sustainable Food Production. Proceedings Of The Nutrition Society, 72(1), 21-28. Https://Doi.Org/10.1017/S0029665112 002832

Stoeckli, S., Hirschi, M., Spirig, C., Calanca, P., \& Rotach, M. W. (2012). Impact Of Climate Change On Voltinism And Prospective Diapause Induction Of A Global Pest Insect-Cydia Pomonella (L.). Plos ONE, 7(4), 35723. Https://Doi.Org/10.1371/Journal.Pone. 
0035723

Tjasyono, B. (2006). Bencana Kebumian Meteorologis.

Tjasyono, B., Badan, H. K., Klimatologi, M., \& Geofisika, D. (2004). Meteorologi Indonesia Volume I Karakteristik Dan Sirkulasi Atmosfer.

Yao, J., He, X., He, H., Chen, W., Dai, L., Lewis, B. J., \& Yu, L. (2015). The Long-Term Effects Of Planting And Harvesting On Secondary Forest Dynamics Under Climate Change In Northeastern China OPEN. Https://Doi.Org/10.1038/Srep18490 